\title{
FISH-mapping of the 5S rDNA locus in chili peppers (Capsicum-Solanaceae)
}

\author{
PATRICIA M. AGUILERA ${ }^{1}$, HUMBERTO J. DEBAT ${ }^{2}$, MARISEL A. \\ SCALDAFERRO ${ }^{3}$, DARDO A. MARTII ${ }^{1}$ and MAURO GRABIELE ${ }^{1}$ \\ 'Instituto de Biología Subtropical, Universidad Nacional de Misiones (IBS-UNaM- \\ CONICET), Félix de Azara 1552, Posadas (3300), Misiones, Argentina \\ ${ }^{2}$ Instituto de Patología Vegetal, Centro de Investigaciones Agropecuarias, Instituto Nacional de Tecnología \\ Agropecuaria (IPAVE-CIAP-INTA), Camino a 60 Cuadras Km 5 1⁄2, Córdoba (X5020ICA), Argentina \\ ${ }^{3}$ Instituto Multidisciplinario de Biología Vegetal, Universidad Nacional de Córdoba (IMBIV- \\ UNC-CONICET), Vélez Sarsfield 1611, Córdoba (X5016GCA), Argentina
}

Manuscript received on November 13, 2014; accepted for publication on January 26, 2015

\begin{abstract}
We present here the physical mapping of the $5 \mathrm{~S}$ rDNA locus in six wild and five cultivated taxa of Capsicum by means of a genus-specific FISH probe. In all taxa, a single $5 \mathrm{~S}$ locus per haploid genome that persistently mapped onto the short arm of a unique metacentric chromosome pair at intercalar position, was found. $5 \mathrm{~S}$ FISH signals of almost the same size and brightness intensity were observed in all the analyzed taxa. This is the first cytological characterization of the $5 \mathrm{~S}$ in wild taxa of Capsicum by using a genus-derived probe, and the most exhaustive and comprehensive in the chili peppers up to now. The information provided here will aid the cytomolecular characterization of pepper germplasm to evaluate variability and can be instrumental to integrate physical, genetic and genomic maps already generated in the genus.
\end{abstract}

Key words: wild and cultivated Capsicum, 5S rRNA gene, Capsicum-derived probe, FISH-mapping.

\section{INTRODUCTION}

Capsicum L., or chili peppers, (Solanaceae) is a New Word genus distributed from Mexico to Argentina that comprises 31 species, several of which are of considerable economic importance. Five Capsicum species ( $C$. annuum L. var. annuum, C. chinense Jacq., C. frutescens L., C. baccatum L. var. pendulum (Willd.) Eshbaugh and var. umbilicatum (Vellozo) Hunz. et Barboza, and C. pubescens Ruiz et Pav.) were domesticated by American natives and are now cultivated as part

Correspondence to: Mauro Grabiele

E-mail: maurograbiele@conicet.gov.ar of the human diet (Moscone et al. 2007). In fact, after tomato, peppers are the most culivated fruit vegetable species in the world (FAOSTAT 2014).

In plants, 5S rRNA genes are organized in one or several loci, arranged as tandem repeats of thousand to hundreds of thousand copies per genome, with each copy comprising a coding region (CR; 120 bp) and a non-transcribed intergenic spacer (NTS; 100-900 bp) (Cloix et al. 2001 and references therein).

Previous fluorescent in situ hybridization (FISH) assays revealed the loci number and localization of the 5S rRNA gene in only a few Capsicum species, by means of different probes, 
some of them derived from unrelated taxa (Park et al. 1999, 2000, Scaldaferro et al. 2006, Kwon and Kim 2009). Similarly, other economically important members of the Solanaceae family such as tomato, tobacco and petunia have been studied to reveal the presence of $5 \mathrm{~S}$ sites (Garcia et al. 2012) but information on potato and eggplant is still absent. In addition, more comprehensive approaches led to the development of several pepper maps ( $\mathrm{Wu}$ et al. 2009 and references therein) and recently, to the genome sequencing of wild and cultivated species of chili peppers (Kim et al. 2014, Qin et al. 2014). However, despite 45S rRNA genes have been mapped onto a pepper genetic linkage map (Wu et al. 2009), information regarding 5S rDNA genes in Capsicum, is still lacking.

The main purpose of this contribution is to achieve a physical mapping of the 5S rDNA locus in wild and cultivated taxa of Capsicum by means of a genus-specific FISH probe. The cytological 5S rDNA marker is highly useful in the identification of individual chromosomes for further germplasm characterization. In addition, the information reported here, not only broadly expands the limited knowledge of 5S rDNA mapping in Capsicum, but will also be undoubtedly useful to integrate physical, genetic and genomic maps already generated in the genus (Tanksley et al. 1988, Kang et al. 1997, Wu et al. 2009, Qin et al. 2014, Kim et al. 2014).

\section{MATERIALS AND METHODS}

PLANT MATERIAL

Five cultivated in addition to six wild taxa of Capsicum were employed to cytologically map the 5S rRNA gene. Taxa, provenances, herbarium specimens and status of the studied material are summarized in Table I. Plant material was determined by Dr. Gloria E. Barboza.

\section{CHROMOSOME PREPARATIONS}

Chromosomes of somatic metaphases were observed in root tip squashes obtained from seed germination. Seeds were placed on moisturized filter paper in Petri dishes and germinated at room temperature (about $25{ }^{\circ} \mathrm{C}$ ). Roots were collected when they reached $2 \mathrm{~cm}$ in length and were immediately pretreated with $p$-dichlorobenzene saturated solution for $3 \mathrm{~h}$ at room temperature and then fixed in Farmer solution (absolute ethanol : glacial acetic acid, $3: 1$ ) for a minimum of $12 \mathrm{~h}$ at $4{ }^{\circ} \mathrm{C}$. Somatic chromosome spreads were prepared following the procedure described by Schwarzacher et al. (1980). Root tips were macerated in $2 \%$ (m/v) cellulase (Onozuka R-10 from Trichoderma viridae; Serva, Heidelberg, Germany) plus 10\% (v/v) pectinase (from Aspergillus niger; Sigma, St. Louis, Missouri, USA), dissolved in $40 \%$ glycerol in $0.01 \mathrm{~mol} / \mathrm{L}$ citric acid/sodium citrate buffer, $\mathrm{pH}$ 4.8 , at $37{ }^{\circ} \mathrm{C}$ for $2 \mathrm{~h}$, and then squashed in $45 \%$ acetic acid. After removal of the coverslip with $\mathrm{CO}_{2}$, slides were air dried, incubated for 1-2 days at room temperature, and then kept at $4{ }^{\circ} \mathrm{C}$ until use.

\section{DNA ISOLATION AND 5S PROBE PREPARATION}

Genomic DNA was isolated and purified from fresh leaves of $C$. pubescens by using the CTAB method, with minor modifications (Rogers and Bendich 1994). An additional step of DNA purification using phenol-chloroform and a RNAse A treatment (Invitrogen, USA) was added, followed by DNA precipitation with ethanol (Sambrook et al. 1989). Sample quality was checked by electrophoresis in agarose $0.8 \%$ gel, and by measurements of Abs. $260 \mathrm{~nm} / 280 \mathrm{~nm}$ index, to confirm DNA integrity and absence of RNA contamination. The 5S rDNA unit of $C$. pubescens was amplified through polymerase chain reaction (PCR) by using two oligonucleotide primers, P1 5'-GATCCCATCAGAACTCC-3' (17mer) and P2 5'-GGTGCTTTAGTGCTGGTAT-3' (19mer) from Park et al. (2000). Both primer sequences bind to the highly conserved sections in the coding region of the $5 \mathrm{~S}$ gene (Fig. 1). The PCR reaction mixture comprised $10 \mathrm{ng}$ of template DNA from 
TABLE I

Summary of 5S rDNA FISH in Capsicum. CORD = Herbarium from Museo Botánico de Córdoba, Argentina; Status: $c=$ cultivated; $\mathbf{w}=$ wild. Collectors: GEB $=$ GE Barboza; YSG $=$ Y Sánchez García; EAM = EA Moscone; Abb =

Abbreviation; $\mathbf{2} n=$ somatic chromosome number; $\mathrm{p}=$ short chromosome $\mathbf{a r m}$; $\mathrm{di}=$ intercalary band distance to the centromere index; $C L=$ chromosome length in $\mu \mathrm{m} ; \mathrm{CI}=$ centromeric index; $\mathrm{RCL}=$ relative chromosome length expressed as percentage of the genome size in $\mu \mathrm{m}$.

\begin{tabular}{|c|c|c|c|c|c|c|c|c|}
\hline Taxa, provenance, herbarium and status & Abb & $2 n$ & $\begin{array}{c}\text { Karyotype } \\
\text { formula }\end{array}$ & \# loci & Position & $\mathbf{C L}$ & CI & RCL \\
\hline $\begin{array}{l}\text { C. chacoense Hunz. Bolivia. GEB et al. 1793-CORD } \\
\text { (w) }\end{array}$ & cha & 24 & $22 m+2 s t$ & 1 & $\begin{array}{c}4 p \\
\mathrm{di}=73.68\end{array}$ & 5.60 & 47.50 & 8.70 \\
\hline $\begin{array}{l}\text { C. cardenasii Heiser et Smith Bolivia. CORD } 1135 \\
\text { (w) }\end{array}$ & car & 24 & $22 \mathrm{~m}+2 \mathrm{sm}$ & 1 & $\begin{aligned} 9 p \\
\mathrm{di}=57.89\end{aligned}$ & 5.53 & 48.10 & 7.25 \\
\hline C. eximium Hunz. Argentina. EAM 255-CORD (w) & exi & 24 & $22 \mathrm{~m}+2 \mathrm{sm}$ & 1 & $\begin{array}{c}6 \mathrm{p} \\
\mathrm{di}=67.50\end{array}$ & 5.80 & 48.28 & 8.29 \\
\hline $\begin{array}{l}\text { C. flexuosum Sendtn. Argentina. GEB et al. 1034- } \\
\text { CORD (w) }\end{array}$ & fle & 24 & $22 m+2 s t$ & 1 & $\begin{aligned} 9 p \\
\mathrm{di}=59.38\end{aligned}$ & 8.17 & 43.70 & 7.85 \\
\hline $\begin{array}{l}\text { C. rhomboideum (Dunal) Kuntze. Venezuela. YSG } \\
\text { 19-CORD (w) }\end{array}$ & rho & 26 & $20 m+2 s m+4 s t$ & 1 & $\begin{aligned} & 3 p \\
\mathrm{di}= & 50.59\end{aligned}$ & 3.50 & 48.57 & 8.68 \\
\hline $\begin{array}{l}\text { C. baccatum L. var. praetermissum Heiser et Smith } \\
\text { Brasil. GEB et al. 1646-CORD (w) }\end{array}$ & pra & 24 & $22 \mathrm{~m}+2 \mathrm{sm}$ & 1 & $\begin{aligned} 7 p \\
\mathrm{di}=59.57\end{aligned}$ & 6.71 & 49.03 & 8.56 \\
\hline $\begin{array}{l}\text { C. annuum L. var. annuum. México. NMCA 10272- } \\
\text { CORD (c) }\end{array}$ & ann & 24 & $20 \mathrm{~m}+2 \mathrm{sm}+2 \mathrm{st}$ & 1 & $\begin{array}{c}3 \mathrm{p} \\
\mathrm{di}=69.52\end{array}$ & 6.07 & 48.11 & 8.67 \\
\hline C. chinense Jacq. Brasil. GEB 807-CORD (c) & chi & 24 & $22 m+2 s t$ & 1 & $\begin{array}{c}3 \mathrm{p} \\
\mathrm{di}=74.40\end{array}$ & 5.23 & 47.80 & 8.52 \\
\hline C. frutescens L. Brasil. GEB 806-CORD (c) & fru & 24 & $22 m+2 s t$ & 1 & $\begin{array}{c}8 \mathrm{p} \\
\mathrm{di}=77.24\end{array}$ & 5.86 & 49.49 & 8.32 \\
\hline $\begin{array}{l}\text { C. baccatum L. var. pendulum (Willd.) Eshbaugh. } \\
\text { Argentina. EAM et al. 211-CORD (c) }\end{array}$ & pen & 24 & $22 m+2 s t$ & 1 & $\begin{array}{c}5 \mathrm{p} \\
\mathrm{di}=76.19\end{array}$ & 6.23 & 47.19 & 8.40 \\
\hline $\begin{array}{l}\text { C. pubescens Ruiz et Pav. Argentina. EAM 256- } \\
\text { CORD (c) }\end{array}$ & pub & 24 & $22 m+2 s t$ & 1 & $\begin{array}{c}3 \mathrm{p} \\
\mathrm{di}=56.86\end{array}$ & 7.35 & 48.57 & 9.16 \\
\hline
\end{tabular}

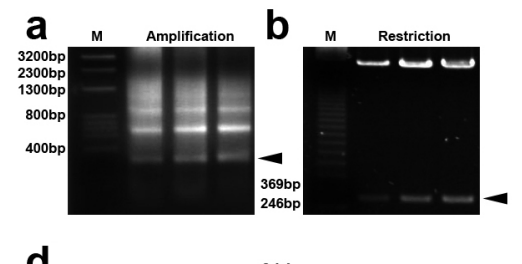

C

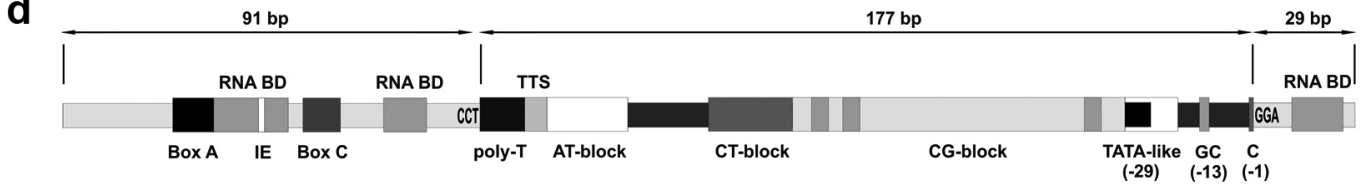

Figure 1 - Development and molecular characterization of the 5S rDNA probe from C. pubescens. (a-b) Gel electrophoresis of the PCR amplification products and clones, respectively, with that related to the FISH probe marked with arrowheads; (c) Amplification strategy according to the 5S rDNA unit organization and primers P1/P2 from Park et al. (2000); (d) Core features of the FISH probe Cp5S-3; in the gene, the internal control region (ICR) formed by the motives Box A, Box C and IE (Cloix et al. 2001) and the RNA binding domains (RNA BD) to the TFIIIA (Kellogg and Appels 1995) are shown; additional features correspond to the non transcribed spacer (NTS); TTS, transcription termination site. 
C. pubescens, $0.5 \mathrm{pmol}$ of each primer, $200 \mathrm{mM}$ of each dNTP, $5 \mu 1$ of $10 \mathrm{X}$ reaction buffer and 1 unit of Taq DNA polymerase "Sequencing Grade" (Promega, USA). Thirty six amplification cycles were performed, each involving denaturation at 94 ${ }^{\circ} \mathrm{C}$ for $1 \mathrm{~min}$, primer annealing at $57^{\circ} \mathrm{C}$ for $1 \mathrm{~min}$, and extension at $72{ }^{\circ} \mathrm{C}$ for $1 \mathrm{~min}$. Amplified 5S rDNA fragments were separated in agarose $1.4 \%$ gel and then were excised from the gel and purified by using the GFX kit (Amersham Pharmacia, USA). Amplified fragments were cloned into the pCR2.1TOPO vector (Invitrogen, USA) and transformed in Escherichia coli "TOP10 One Shot" (Invitrogen, USA), following the manufacturer's instructions. The obtained clones were grown in LB liquid selective medium. Plasmidic DNA was isolated through mini-preparations, digested with restriction enzymes and visualized in agarose $1 \%$ gel to check the insert stability. The nucleotide sequences of the clones were determined (Macrogen, Korea) and Cp5S-3 was characterized (Fig. 1) and selected for further FISH analysis.

FLUORESCENCE in situ HYBRIDIZATION

FISH experiments were undertaken according to Moscone et al. (1996). The obtained clone Cp5S-3 was labeled by nick translation with digoxigenin11-dUTP following the manufacturer instructions (Enzo, USA) to generate a ribosomal DNA probe. Slide preparations were subjected to RNAse and Proteinase K pretreatments, followed by steps of denaturalization, probe hybridization, blocking, probe detection by means of antibodies linked to fluorochromes [anti-digoxigenin to fluorescein (FITC)] (Dako, USA), washing, and DAPI staining for contrast.

\section{FLUORESCENCE MICROSCOPY AND IMAGE ACQUISITION}

Chromosomes were viewed and photographed with an Olympus BX50 fluorescence microscope equipped with a computer-assisted digital camera system. Images were captured in black and white using appropriate filters for FITC and DAPI excitation, respectively. Digital images were combined in Photoshop 7.0 (Adobe, San Jose, California, USA) for final processing.

\section{KARYOTYPE ANALYSIS}

At least five metaphase plates per taxa were used for chromosome measurements. The centromeric index $(C I=$ short arm length $\mathrm{x} 100 /$ chromosome length) was used to classify the chromosomes according to Levan et al. (1964) in metacentric (m; $\mathrm{CI}=50-37.51)$, submetacentric ( $\mathrm{sm} ; \mathrm{CI}=37.50$ 25.10) and subtelocentric (st; $\mathrm{CI}=25.00-12.51$ ). Different lengths of the same arm (and band/locus, where applicable) from homologous chromosomes were combined to mean values and represented in the haploid complements of the idiograms. Intercalary markers were mapped using the index $\mathrm{di}=\mathrm{d} \times 100 / \mathrm{a}(\mathrm{d}=$ distance of band center from the centromere; $\mathrm{a}=$ length of the corresponding chromosome arm) according to Greilhuber and Speta (1976).

\section{RESULTS}

GENUS SPECIFIC PROBE DEVELOPMENT AND CHARACTERIZATION

The generation and molecular characterization of the 5S rDNA probe from C. pubescens is displayed in Figure 1a-d. Clone Cp5S-3 is 297 bp in length and exhibits, at the sequence level, all the specific features of functional 5S rDNA units.

\section{FISH EXPERIMENTS}

A Capsicum-derived rDNA probe (Cp5S-3) was used in FISH experiments in order to cytologically map the 5S rDNA locus in the chili peppers. The somatic chromosome number added to the karyotype formula and the number and position of the 5S rDNA loci per diploid complement in the analyzed taxa are summarized in Table I. Additional features associated to the chromosome that carries 
the 5S rDNA are also provided in Table I, i.e. the chromosome length (CL), the centromeric index (CI) and the relative chromosome length (RCL). All the studied taxa are diploid and have $2 n=24$, except for $C$. rhomboideum (Dunal) Kuntze which has $2 n=26$ chromosomes. Karyotype formula varied among taxa but symmetry is a core feature in Capsicum.

LOCI NUMBER, SIZE AND DISTRIBUTION

FISH experiments revealed a unique chromosome pair hybridized with the Cp5S-3 probe (green dots) in the eleven examined taxa (Fig. 2a). Polymorphisms for these loci within individuals or between taxa were not observed. Therefore, a single 5S locus per haploid genome was found in Capsicum. 5S FISH signals of almost the same size and brightness intensity were observed in the studied taxa of Capsicum (Fig. 2a, b). In the analyzed taxa, the 5S rDNA locus persistently mapped onto the short arm of a unique metacentric chromosome pair, at intercalar position (Fig. 2a). Four species, i.e. C. rhomboideum, C. annuum var. annuum, $C$. chinense and C. pubescens, carried the 5S locus on the chromosome pair \#3. Capsicum chacoense Hunz. exhibited the 5S locus onto pair \#4. In addition, C. baccatum var. pendulum, C. eximium Hunz., C. baccatum var. praetermissum Heiser et Smith and $C$. frutescens bore the $5 \mathrm{~S}$ locus in pairs \#5, 6, 7 and 8, respectively. In C. cardenasii Heiser et Smith and C. flexuosum Sendtn. 5S signals were located on pair \#9. The distance of the $5 \mathrm{~S}$ locus to the centromere, measured as the intercalar distance index (di), averaged $65.71( \pm 9.19)$ and ranged from 50.59 (in C. rhomboideum) to 77.24 (in $C$. frutescens) (Table I and Fig. 2b).

\section{DISCUSSION}

\section{FISH PROBE CHARACTERIZATION}

According to genic and non transcribed spacer (NTS) motives, the FISH probe derived clone
Cp5S-3 is fairly representative of functional $5 \mathrm{~S}$ segments. Gene features, i.e. the internal control region (ICR) formed by the motives Box A, Box C and IE of Cloix et al. (2001) and the RNA binding domains (RNA BD) to the TFIIIA (Kellogg and Appels 1995), were identified in the primary sequence and are represented in Figure 1d. Further structures in the NTS, i.e. the transcription termination site (TTS) and the TATA-like box $(-29)$, the GC dinucleotides (-13) and the C (-1) at 3 'end region, are also associated to functionality (Cloix et al. 2001).

\section{FISH EXPERIMENTS}

Cytological mapping of the 5S has been previously performed in several chili peppers. Scaldaferro et al. (2006) used a probe derived from Beta vulgaris (pXV1) on wild and cultivated taxa. Furthermore, Park et al. $(1999,2000)$ used a wheat derived-probe (pScT7) and a Capsicum-related one, respectively, on cultivated taxa, the same as Kwon and Kim (2009). However, ours is the first report on the cytological characterization of the $5 \mathrm{~S}$ in wild taxa of Capsicum by using a genus-specific FISH probe. Moreover, our results in C. eximium, C. flexuosum, C. rhomboideum and both wild and cultivated varieties of $C$. baccatum (praetermissum and pendulum) are novel in the genus. Furthermore, considering the number of analyzed taxa, our contribution is the most exhaustive and extensive characterization of the $5 \mathrm{~S}$ locus in chili peppers.

\section{LOCI NUMBER AND DISTRIBUTION}

Our results on the FISH location in the wild and cultivated taxa of Capsicum revealed a single $5 \mathrm{~S}$ locus per haploid genome. This locus is regularly mapped onto the short arm of a unique metacentric chromosome pair of approximately the same size among taxa, with the exception of the CL of $C$. flexuosum and C. rhomboideum. All the analyzed taxa exhibited the $5 \mathrm{~S}$ locus at an intercalar position, which is closer to the distal portion of the short 


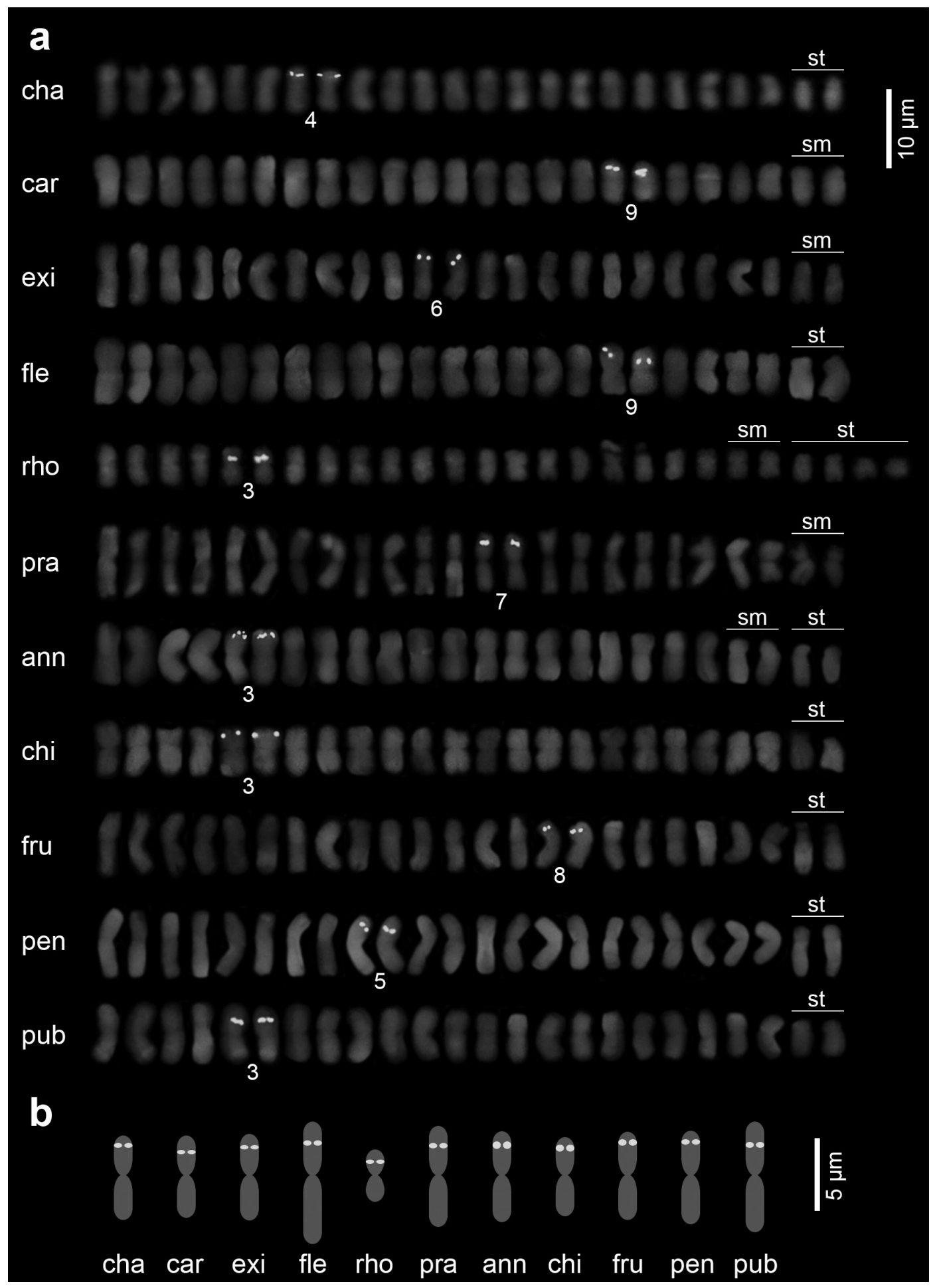

Figure 2 - Physical mapping of the 5S rDNA locus in the wild and cultivated Capsicum taxa by means of FISH. (a) Well-arranged karyograms derived from DAPI (blue) stained somatic metaphase plates showing the number and position of the 5S rDNA locus (green dots) added to further elementary cytological features; chromosomes other than metacentric (m) are solely marked (sm, st); (b) Schematic depiction of the chromosomes that carry the 5S rDNA locus considering the mean values described in Table I; green dots size relates to the mean fluorescence intensity. (See the colors in the on-line version). 
arm, rather than to the centromere, except for the di value of $C$. rhomboideum. The metacentric chromosome pair that carries the $5 \mathrm{~S}$ locus resulted homeologous among these taxa. These results are in agreement with previous reports in Capsicum. A sole and short arm intercalar 5S rDNA locus (two FISH signals) was also observed in C. annuum var. annuum, $C$. chinense, $C$ frutescens, $C$. baccatum var. umbilicatum, $C$. pubescens, $C$. chacoense and C. cardenasii, all of them of distinct provenance regarding our plant material (Park et al. 1999, 2000, Scaldaferro et al. 2006, Kwon and Kim 2009). Altogether, the combined results evidence the universality of this cytological feature in Capsicum. Physical location of the 5S in the same chromosome pair regarding our accessions and those of Scaldaferro et al. (2006), was also found in C. cardenasii (\#9), C. pubescens (\#3) and cultivated varieties of C. baccatum (\#5). In contrast to the latter authors who found the $5 \mathrm{~S}$ loci at the chromosome pair \#6 of C. annuum var. annuum, we detected it at \#3. According to Park et al. (2000), the 5S loci in the cultivated taxa of Capsicum was assigned to chromosome 1 by the synteny relationship with the corresponding linkage group of tomato, of Lapitan et al. (1991). Furthermore, Kwon and Kim (2009) assigned the 5S loci of $C$. annuum to the linkage group 7 of the genetic map of Kang et al. (1997). However, the $5 \mathrm{~S}$ loci was not mapped in the recent contributions of the genome of chili peppers (Qin et al. 2014, Kim et al. 2014).

LOCI SIZE

5S FISH signals of almost the same size and brightness intensity were observed in the studied taxa of Capsicum. In essence, this feature suggests similar ribosomal copy number in the $5 \mathrm{~S}$ per genome in the genus. However, Giemsa-C and fluorescence bandings revealed a Giemsa+ and CMA+DAPI- constitutive heterochromatic region (Het) located at the short arm of a unique metacentric chromosome pair at intercalar position, in diverse chili peppers (Moscone et al. 2007 and references therein; Scaldaferro et al. 2013), that in fact co-localize with the $5 \mathrm{~S}$ loci. This Het is polymorphic among taxa, regarding presence and size, suggesting variability in the $5 \mathrm{~S}$ ribosomal copy number in Capsicum. In this regard, the expression level of the 5S rRNA gene is, in part, regulated by transcriptional inactivation, associated to citosine methylation, mediated by siRNAs, as occur in the 18S-25S rRNA and other repetitive sequences. The heterochromatic state of those loci is more conspicuous at higher copy numbers (Neves et al. 2005, Pontes et al. 2006, Daxinger et al. 2009). In addition, the only report on the copy number of the $5 \mathrm{~S}$ in Capsicum is that of Kwon and Kim (2009) in extended DNA fibers of $C$. annuum, who estimated it in 1453 copies per haploid genome.

5S IN SOLANACEAE

In addition to chili peppers, the family contains other economically important species such as tomato, potato, tobacco and eggplant. Considering all Solanaceae in the rDNA Plant database (www. plantrdnadatabase.com), a single 5S rDNA locus per haploid genome is common in diploid taxa, with some exceptions (Garcia et al. 2012). Particularly, the cultivated taxa exhibit a single (tomato), a single or double (petunia) and a double (tobacco, a polyploid taxon) 5S rDNA locus per haploid genome, however, this information is not available for the $5 \mathrm{~S}$ of potato and eggplant (Garcia et al. 2012).

\section{CONCLUSIONS}

The main purpose of this contribution was to achieve a physical mapping of the 5S rDNA locus in wild and cultivated taxa of Capsicum by means of a genus-specific FISH probe. This cytological marker is useful to identify individual chromosomes in order to assist the cytomolecular characterization of pepper germplasm by the evaluation of inter and 
intraspecific cytogenetic variability. Additionally, the information reported here can be used to integrate physical, genetic and genomic maps already generated in the genus which undoubtedly will represent a valuable tool for breeding purposes of chili peppers.

\section{RESUMO}

Neste trabalho, apresentamos o mapeamento físico do locus $5 \mathrm{~S}$ rDNA em seis taxa silvestres e cinco cultivados de Capsicum, obtido através do uso de uma sonda FISH gênero-específica. Em todos os taxa, um único locus 5S por genoma haplóide foi persistentemente mapeado no braço curto de um único par de cromossomos metacêntricos na posição intercalar, e foram observados sinais $5 \mathrm{~S}$ de FISH de tamanho e intensidade de brilho quase semelhantes. Esta é a primeira caracterização citológica dos $5 \mathrm{~S}$ nos taxa silvestres de Capsicum usando uma sonda gênero-específica e o estudo sobre o grupo das pimentas mais exaustivo e abrangente realizado até ao momento. A informação aqui fornecida irá ajudar a caracterização citomolecular do germoplasma das pimentas, permitindo avaliar a sua variabilidade $\mathrm{e}$ podendo ser usada para integrar mapas físicos, genéticos e genômicos já realizados no gênero.

Palavras-chave: Capsicum cultivados e silvestres, gene de rRNA 5S, sonda derivada do Capsicum, mapeamento FISH.

\section{ACKNOWLEDGMENTS}

This study was supported by Consejo Nacional de Investigaciones Científicas y Técnicas (CONICETArgentina) with a postdoctoral research fellowship to P.M.A. and M.A.S. and a career membership to M.G. and D.A.M. Additional support was provided by Instituto Nacional de Tecnología Agropecuaria (INTA-Argentina) to H.J.D. Authors would also like to thank Dr. Gloria E. Barboza who determined the plant material.

\section{REFERENCES}

Cloix C, Tutois S, Yukawa Y, Mathieu O, CuVILlier C, ESPAGNOL MC, PICARD G AND TOURMENTE S. 2001.
Analysis of the 5S RNA Pool in Arabidopsis thaliana: RNAs are heterogeneous and only two of the genomic $5 \mathrm{~S}$ loci produce mature RNA. Genome Res 12: 132-144.

DAXINGER L, KANNO T, BUCHER E, VAN DER WINDEN J, NAUMANN U, MATZKE AJ AND MATZKE MA. 2009. Stepwise pathway for biogenesis of 24-nt secondary siRNAs and spreading of DNA methylation. EMBO J 28: 48-57.

FAOSTAT - FOOD AND AGRICULTURE ORGANIZATION OF THE UNITED NATIONS. 2014. Food and Agriculture Organization (FAO) of the United Nations. http://faostat. fao.org/site/339/default.aspx. Accessed: 10/30/2014.

GARCIA S, GARNATJE T AND KOVARIK A. 2012. Plant rDNA database: ribosomal DNA loci Information goes online. Chromosoma 121: 389-394.

GREILHUBER J AND SPETA F. 1976. C-banded karyotypes in the Scilla hohenackeri group, S. persica, and Puschkinia (Liliaceae). Plant Syst Evol 126: 149-188.

KANG BC, YU JW, LEE MH AND KIM BD. 1997. Applicability of AFLP on hot pepper genetic analysis. J Kor Soc Hort Sci 38: 698-703.

KELLOGG EA AND APPELS R. 1995. Intraspecific and interspecific variation in 5S RNA genes are decoupled in diploid wheat relatives. Genetics 140: 325-343.

KIM S, PARK M, YEOM SI, KIM YM, LEE JM, LEE HA AND SEO E. 2014. Genome sequence of the hot pepper provides insights into the evolution of pungency in Capsicum species. Nat Genet 46: 270-278.

KWON JK AND KIM BD. 2009. Localization of 5S and 25S rRNA genes on somatic and meiotic chromosomes in Capsicum species of chili pepper. Mol Cells 27: 205-209.

LAPITAN NL, GANAL MW AND TANKSLEY SD. 1991. Organization of the $5 \mathrm{~S}$ ribosomal RNA genes in the genome of tomato. Genome 34: 509-514.

LEVAN A, FREDGA KL AND SANDBERG AA. 1964. Nomenclature for centromeric position on chromosomes. Hereditas 52: 201-220.

Moscone EA, MATZKE MA AND MATZKE AJ. 1996. The use of combined FISH/GISH in conjunction with DAPI counterstaining to identify chromosomes containing transgene inserts in amphidiploid tobacco. Chromosoma 105: 231236.

MOSCONE EA, SCALDAFERRO MA, GRABIELE M, CECCHINI NM, SÁNCHEZ GARCÍA Y, JARRET R, DAVIÑA JR, DUCASSE DA, BARBOZA GE AND EHRENDOFER F. 2007. The evolution of chili peppers (Capsicum-Solanaceae): a cytogenetic perspective. Acta Hortic 745: 137-169.

Neves N, Delgado M, Silva M, CAPerta A, MoraisCECÍlio L AND Viegas W. 2005. Ribosomal DNA heterochromatin in plants. Cytogenet Genome Res 109: 104-111.

PARK YK, KIM BD, KIM BS, ARMSTRONG KC AND KIM NS. 1999. Karyotyping of the chromosomes and physical mapping of the 5S rRNA and 18S-26S rRNA gene families 
in five different species in Capsicum. Genes Genet Syst 74: 149-157.

PARK YK, PARK KC, PARK CH AND KIM NS. 2000. Chromosomal localization and sequence variation of $5 \mathrm{~S}$ rRNA gene in five Capsicum species. Mol Cells 10: 18-24.

Pontes O, Li CF, Costa Nunes P, haAg J, ReAm T, Vitins A, JACOBSEN SE AND PIKAARD CS. 2006. The Arabidopsis chromatin-modifying nuclear siRNA pathway involves a nucleolar RNA processing center. Cell 126: 7992.

QIN C, YU C, SHEN Y, FANG X, CHEN L, MiN J AND CHENG J. 2014. Whole-genome sequencing of cultivated and wild peppers provides insights into Capsicum domestication and specialization. Proc Natl Acad Sci USA 111: 51355140.

ROGERS SO AND BENDICH AJ. 1994. Extraction of total cellular DNA from plant, algae and fungi. In: Stanton BG and Schilperoort RA (Eds), A plant molecular biololgy manual. Kluwer Academic Publishers, Dordrecht, p. D1/1-8.

SAMBROOK J, FRITSCH EF AND MANIATIS T. 1989. Molecular cloning: a laboratory manual. $2^{\text {nd }}$ ed., Cold Spring Harbor Laboratory Press, Cold Spring Harbor, NY, 1626 p.
SCALDAFERro MA, GRABIELE M AND MOSCONE EA. 2013. Heterochromatin type, amount and distribution in wild species of chili peppers (Capsicum, Solanaceae). Genet Resour Crop Evol 60: 693-709.

SCALDAFERro MA, SEIJo JG, ACOSTA MC, BARboza GE, DuCAsse DA AND Moscone EA. 2006. Genomic characterization of the germplasm in peppers (CapsicumSolanaceae) by fluorescent in situ hybridization. Plant Sci 43: 291-297.

SCHWARZACHER T, AMBROS P AND SCHWEIZER D. 1980. Application of Giemsa banding to orchid karyotype analysis. Plant Syst Evol 134: 293-297.

TANKSLEY SD, BERNATZKY R, LAPITAN NL AND PRINCE JP. 1988. Conservation of gene repertoire but not gene order in pepper and tomato. Proc Natl Acad Sci USA 85: 64196423.

Wu F, EANNETTA NT, XU Y, DURRETT R, MAZOUREK M, JAHN MM AND TANKSLEY SD. 2009. A COSII genetic map of the pepper genome provides a detailed picture of synteny with tomato and new insights into recent chromosome evolution in the genus Capsicum. Theor Appl Genet 118: 1279-1293. 